\title{
Thermodynamic Investigation of a Shared Cogeneration System with Electrical Cars for Northern Europe Climate
}

\author{
Giulio Vialetto*1, Marco Noro' ${ }^{2}$, Masoud Rokni ${ }^{3}$ \\ ${ }^{1}$ Department of Management and Engineering, University of Padua, Stradella S. Nicola 3, \\ 36100 Vicenza, Italy \\ KValue Srl, Via Enrico Fermi, 36100 Vicenza, Italy \\ e-mail: giulio@giuliovialetto.it \\ ${ }^{2}$ Department of Management and Engineering, University of Padua, Stradella S. Nicola 3, \\ 36100 Vicenza, Italy \\ e-mail: marco.noro@unipd.it \\ ${ }^{3}$ Department of Mechanical Engineering, Technical University of Denmark, Nils Koppels Alle, \\ Lyngby, Denmark \\ e-mail: $\underline{\text { mr@mek.dtu.dk }}$
}

Cite as: Vialetto, G., Noro, M., Rokni, M., Thermodynamic Investigation of a Shared Cogeneration System with Electrical Cars for Northern Europe Climate, J. sustain. dev. energy water environ. syst., 5(4), pp 590-607, 2017, DOI: http://dx.doi.org/10.13044/j.sdewes.d5.0162

\begin{abstract}
Transition to alternative energy systems is indicated by EU Commission as a suitable path to energy efficiency and energy saving in the next years. The aims are to decrease greenhouses gases emissions, relevance of fossil fuels in energy production and energy dependence on extra-EU countries. These goals can be achieved increasing renewable energy sources and/or efficiency on energy production processes. In this paper an innovative micro-cogeneration system for household application is presented: it covers heating, domestic hot water and electricity demands for a residential user. Solid oxide fuel cells, heat pump and Stirling engine are utilised as a system to achieve high energy conversion efficiency. A transition from traditional petrol cars to electric mobility is also considered and simulated here. Different types of fuel are considered to demonstrate the high versatility of the simulated cogeneration system by changing the pre-reformer of the fuel cell. Thermodynamic analysis is performed to prove high efficiency with the different fuels.
\end{abstract}

\section{KEYWORDS}

Solid oxide fuel cells, Fuel cell, Household application, Electric vehicle, Stirling engine, Heat pump, Alternative fuel.

\section{INTRODUCTION}

Last published report of Technical University of Denmark analysed energy systems emphasis [1] in particular the interaction between industrial, domestic and transport consumptions in Denmark. A key issue for the next future was pointed out to be to decrease the use of fossil fuels and replacing it with renewable energies along with a strong improvement in energy efficiency, even though specific strategies must be taken

\footnotetext{
* Corresponding author
} 
for renewable capacity firming. Other different studies are also reported in the literature on this subject. In [2] a chain analysis of the energetic performance of synthetic natural gas including the upstream, midstream and downstream part was reported. The model was designed to analyse the performance of biomass to synthetic natural gas chain and to estimate the effect of $1 \%$ synthetic natural gas in the energy system. In [3] the authors analysed the potential energy benefits and drawbacks coming from the application and deployment of hydrogen technologies for static power and heat production based on the state-of-the-art to face the energy transition. Another study [4] analysed the energy performance of an internal combustion engine fuelled with an environmental friendly fuel, such as Hydrogen-natural gas mixtures $\left(\mathrm{H}_{2} \mathrm{NG}\right)$, as the bridge technology towards the forthcoming pure hydrogen economy. In [5] the effects of coolant temperature in engines using biofuel were described. The efficiency of combustion process and carbon dioxide emissions were observed to increase with temperature, while carbon monoxide, oxygen and lambda values were observed to decrease with temperature.

Other studies had the main goal to analyse the complete elimination of Carbon dioxide $\left(\mathrm{CO}_{2}\right)$ emissions of a city while keeping the power frequency of the grid within prescribed limits, adopting a distributed generation architecture to permit local autonomous operation of the system by the local generation of power [6].

Moreover, electric cars and electric mobility are open topics of research [1] with the aim to decrease environmental impact of transport sector. Different studies show that electrical mobility has an environmental impact that is strictly related to the energy sources used to produce electricity [7]. For example, greenhouse gas emissions can be avoided only if renewable energy sources are used. Electrical mobility has been already studied in relation to the possibility of domestic charging in e.g. [8]. The possibility of using electric cars and their batteries as energy storage systems to stabilize electric systems in scenarios where the majority of the total energy demand is supplied by renewable energy was also analysed (see e.g. $[9,10])$. A possible drawback is related to energy storage due to the fact that batteries provide lower energy storage than hydrocarbon fuels and they are heavier (when comparing for example in $\mathrm{kWh} / \mathrm{kg}$ ).

Meanwhile micro-cogeneration energy systems for household application were also proposed to increase efficiency for a better matching between demand and production and also decrease transmission losses [4, 11]. Different micro-cogeneration systems were proposed, analysed and studied. In [12] a dynamic simulation model for the micro-cogeneration unit based on internal combustion engine was built as a new component on TRNSYS, the model was validated by the experiment data during steady and dynamic processes. In [13] a techno-economic evaluation of retrofitting reciprocating internal combustion engine based cogeneration into existing Canadian houses for the purpose of achieving or approaching net-zero energy rating was presented. The simulations based on primary energy and electricity consumption and associated greenhouse gas emissions revealed the economic profitability in different Canadian climates. Also, Stirling engines were analysed: for example, in [14] the authors presented a test results for a $\mu \mathrm{CHP}$ with the Stirling engine for the most frequently used working gases (helium, nitrogen, air, and argon). The influence of the heat source temperature on the performance of the micro-cogeneration system, efficiency, and the effect of maximal power as function of pressure were presented. A similar study was conducted in [15], based on experimental and numerical analysis of a commercial unit generating $8 \mathrm{~kW}$ of hot water (up to $15 \mathrm{~kW}$ with an auxiliary burner) and $1 \mathrm{~kW}$ of electricity burning natural gas. Brandoni et al. and Maghanki et al. $[16,17]$ analysed a very high range of micro combined heat and power solutions, above all fuel cells, revealed high potential in reducing the greenhouse gas emissions. Investigations on the effect of various parameters (such as condensation and evaporation temperatures, superheating and installing a recuperator) on the performance of a micro-scale tri/co-generation system based on the 
joint operation of an Organic Rankine Cycle (ORC) and a Vapour Compression Cycle (VCC) were carried out in [18]. A similar study for a single-family located in Italy based on a biomass-fired ORC system was reported in [19]. Thu et al. [20] conveyed a study of a micro gas turbine cogeneration system and analysed the part load and full load operation in terms of both first and second laws. Moreover, a small hybrid cycle consisting of a commercially available micro-steam turbine as bottoming cycle (steam expander) and an automotive turbocharger as toping cycle was simulated through an optimization procedure based on a genetic algorithm in [21]. The results of simulations indicated that such novel typology of hybrid cycles (combined cycles) have the potential to be cost-effective with high level of efficiency. An interesting option are also Photovoltaic (PV) cogeneration modules, where useful heat can be recovered by cooling the PV cells (thus increasing their electrical efficiency) was studied in [22]. An experimental analysis of some kinds of modules demonstrated that the thermal and electrical efficiencies are determined by mass flow of cooling water, the inlet temperature and the solar radiation [23]. Heat pumps were also proposed to achieve high efficiency system for hot water production in [24] and cogeneration systems by integrating the heating systems were also proposed to attain better electricity and heat demands (for the user) in Northern [25] and Mediterranean [26] climates.

In this paper, an integrated system with Solid Oxide Fuel Cell (SOFC), Stirling engine, Ground Source Heat Pump (GSHP) and water tank is proposed for a group of five houses. The effect of different types of fuel as input for the systems is also analysed, wherein SOFC produces electricity with high efficiency, heat pump covers part of the heating demand and Stirling engine is used to increase electricity production when heating request is low and at the same time electricity request is high. Electric mobility is proposed with the aim of simulating a future scenario, when electric cars will have a higher penetration into the transport sector [27]. Energy performance of the system is analysed and primary energy saving with respect to a traditional solution is depicted. Such study is completely new and has not been investigated elsewhere.

\section{DESCRIPTION OF THE SYSTEM}

The innovative system proposed here is set up by a SOFC system to produce electricity and heat, and a GSHP to cover part of heating demand. A Stirling engine is also used for the cases when electricity produced by the fuel cell is not enough to face the electricity demand and/or heat demand is low. SOFC system is fed with different fuels such as Ammonia, Dimethyl Ether (DME), Ethanol, Methanol and Natural Gas (NG). The system includes a water tank to store heat produced by the system in case of mismatching between production and demand, to prevent heat dissipation and to increase overall efficiency of the system. An auxiliary electric heater is also added to support GSHP to manage peak heat demands. Figure 1 represents the main energy fluxes.

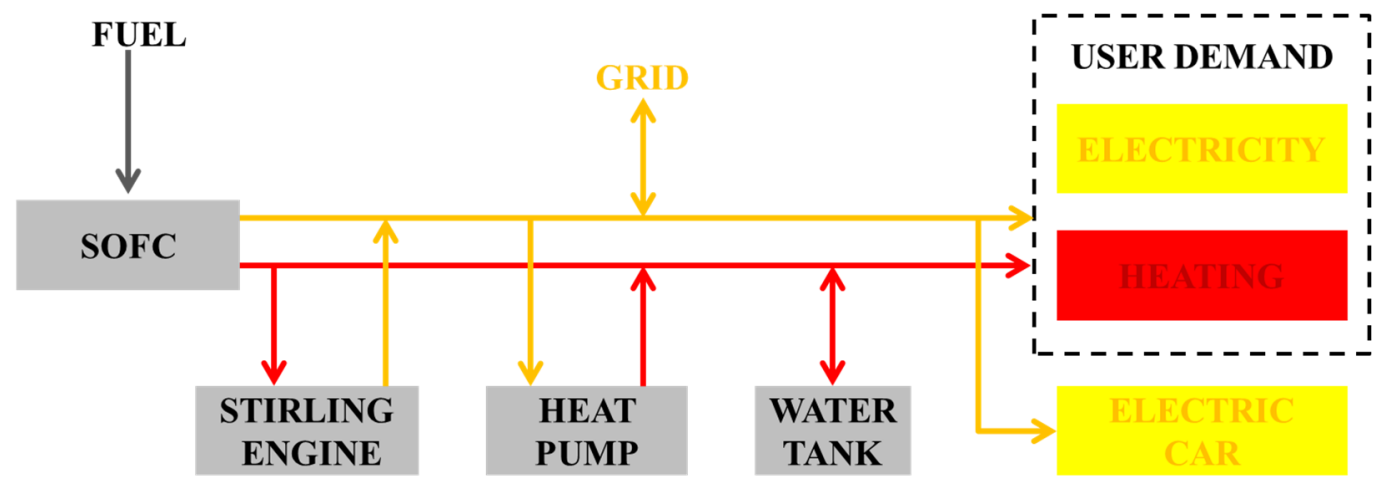

Figure 1. Schematic of the micro-cogeneration system with energy fluxes 
A centralized cogeneration system is supposed to satisfy energy demand from a group of five houses, while each house has been simulated by the program TRNSYS [28] to determine its heating load. It is assumed that in each house there is an Electric Vehicle (EV) whose energy request for charging is covered by the cogeneration system as well.

\section{Solid oxide fuel cell system}

SOFC is the main component of the system proposed here. It provides electricity with high efficiency for the user ( 0.522 is the nominal electrical efficiency), and it supplies the electricity to the GSHP as well electricity for charging the electric vehicle. Heat at high temperature $\left(780{ }^{\circ} \mathrm{C}\right.$ ) produced by SOFC is recovered to feed the Stirling engine. The fuel cell model is already proposed in $[25,26,29]$ with a nominal electric power of $10 \mathrm{~kW}$ which is also adapted for the simulation of the system proposed here (Table 1). The model is slightly modified for using in different configurations in order to simulate different types of fuel in input as described in [29]. In this study, ammonia, DME, ethanol, methanol and NG are considered, with the following specifications:

- SOFC fed with ammonia features the simplest system, as only a fuel pre-heater is required (see Figure 2 and Figure 3);

- SOFC fed with DME, ethanol and methanol is designed with a methanator to reform the fuel (as in Figure 4 and Figure 5);

- SOFC fed with natural gas requires a desulfurizer (to avoid sulphur poisoning in SOFC) and Catalytic Partial Oxidation (CPO) reformer to crack down the heavier hydrocarbons (see Figure 6 and Figure 7).

Table 1. Rated data of the system main equipment

\begin{tabular}{ccccc}
\hline $\begin{array}{c}\text { SOFC (nominal } \\
\text { electric power) } \\
{[\mathrm{kW}]}\end{array}$ & $\begin{array}{c}\text { Stirling engine } \\
\text { (nominal } \\
\text { electric power) } \\
{[\mathrm{kW}]}\end{array}$ & $\begin{array}{c}\text { GSHP (nominal } \\
\text { thermal power) } \\
{[\mathrm{kW}]}\end{array}$ & $\begin{array}{c}\text { GSHP } \\
\text { (COP at full load) } \\
(\mathrm{W} 10 / \mathrm{W} 35)\end{array}$ & $\begin{array}{c}\text { Water tank } \\
\text { (capacity) }[\mathrm{L}]\end{array}$ \\
\hline 10 & 1.3 & 35 & 5.1 & 1,000 \\
\hline
\end{tabular}

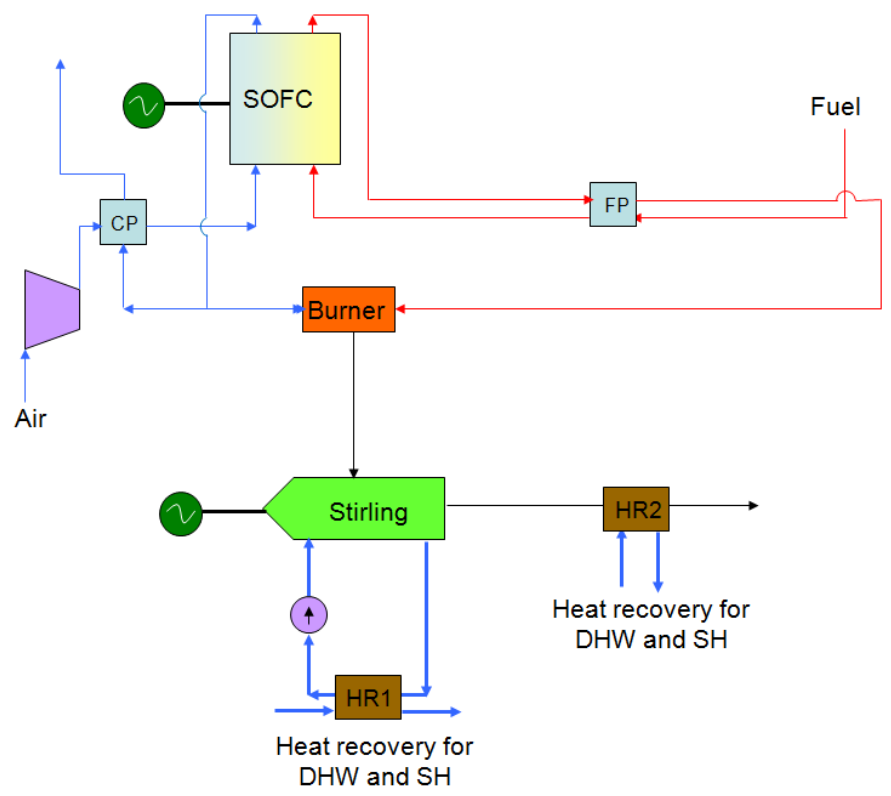

Figure 2. SOFC micro-cogeneration system with Stirling engine fuelled by ammonia [Cathode Pre-heater (CP), Fuel Pre-heater (FP), Heat exchangers for heat recovery (HR1 and HR2) for Domestic Hot Water (DHW) and Space Heating (SH)] 


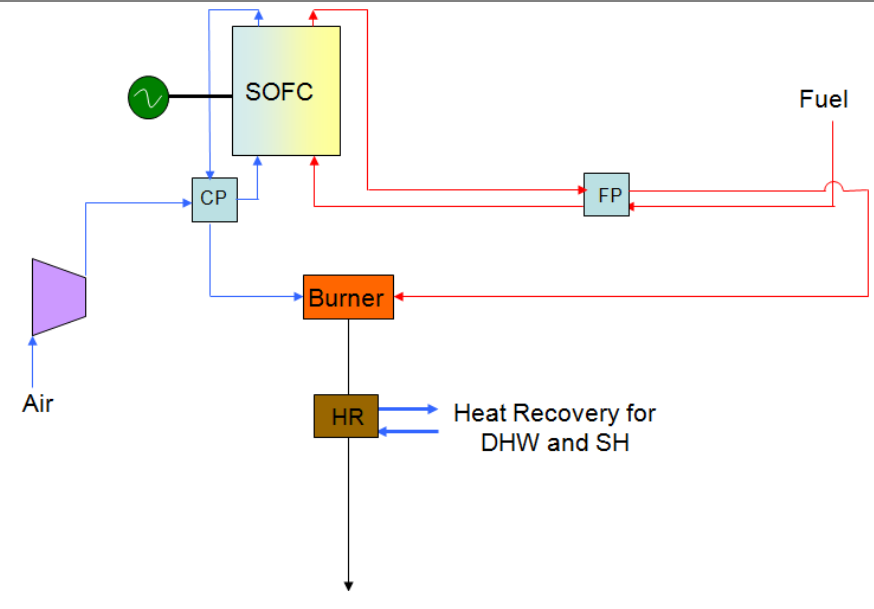

Figure 3. SOFC micro-cogeneration system (stand-alone) fuelled by ammonia [Cathode Pre-heater (CP), Fuel Pre-heater (FP), Heat exchanger (HR) for heat recovery for Domestic Hot Water (DHW) and Space Heating (SH)]

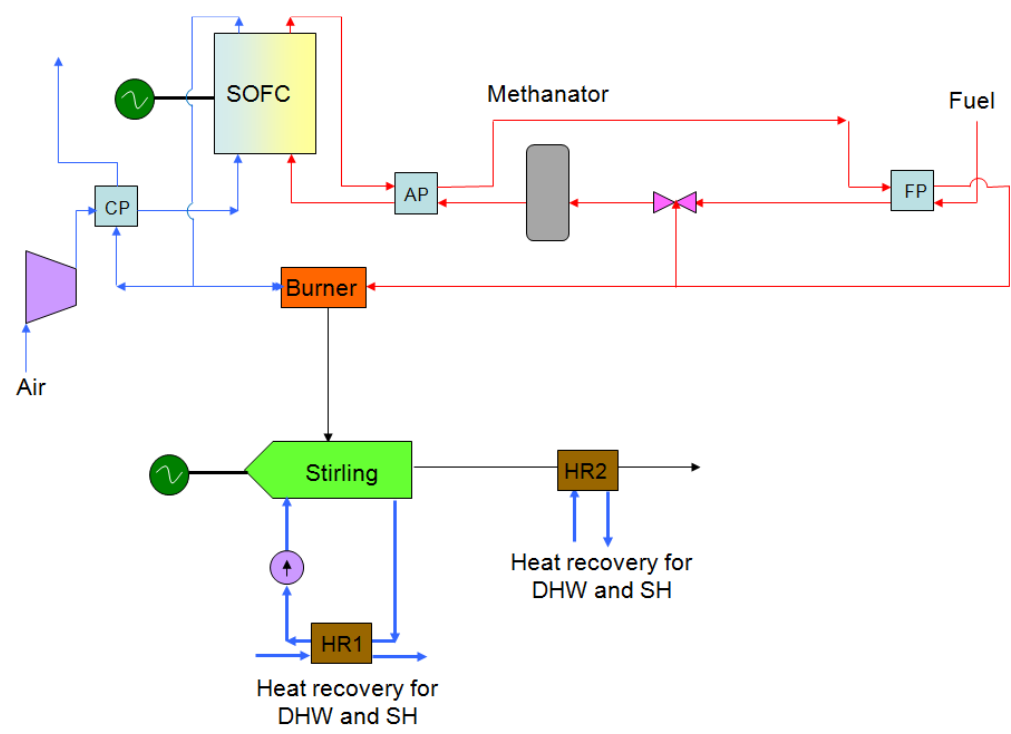

Figure 4. SOFC micro-cogeneration system with Stirling engine fuelled by DME, ethanol or methanol [Cathode Pre-heater (CP), Fuel Pre-heater (FP), Heat exchangers (HR1 and HR2) for heat recovery for Domestic Hot Water (DHW) and Space Heating (SH), Air Pre-heater (AP)]

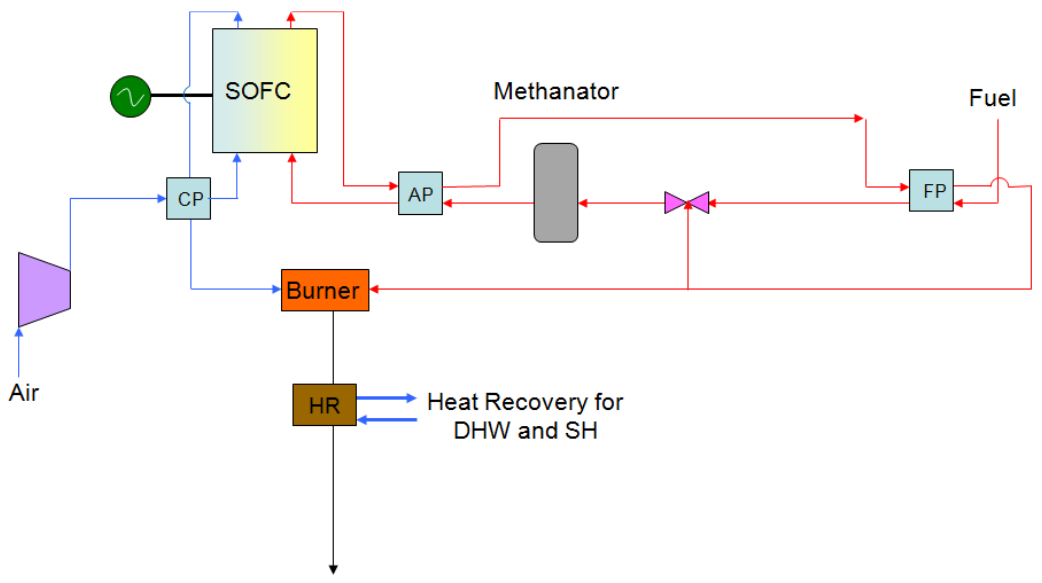

Figure 5. SOFC micro-cogeneration system (stand-alone) fuelled by DME, ethanol or methanol [Cathode Pre-heater (CP), Fuel Pre-heater (FP), Heat exchanger (HR) for heat recovery for Domestic Hot Water (DHW) and Space Heating (SH), Air Pre-heater (AP)] 


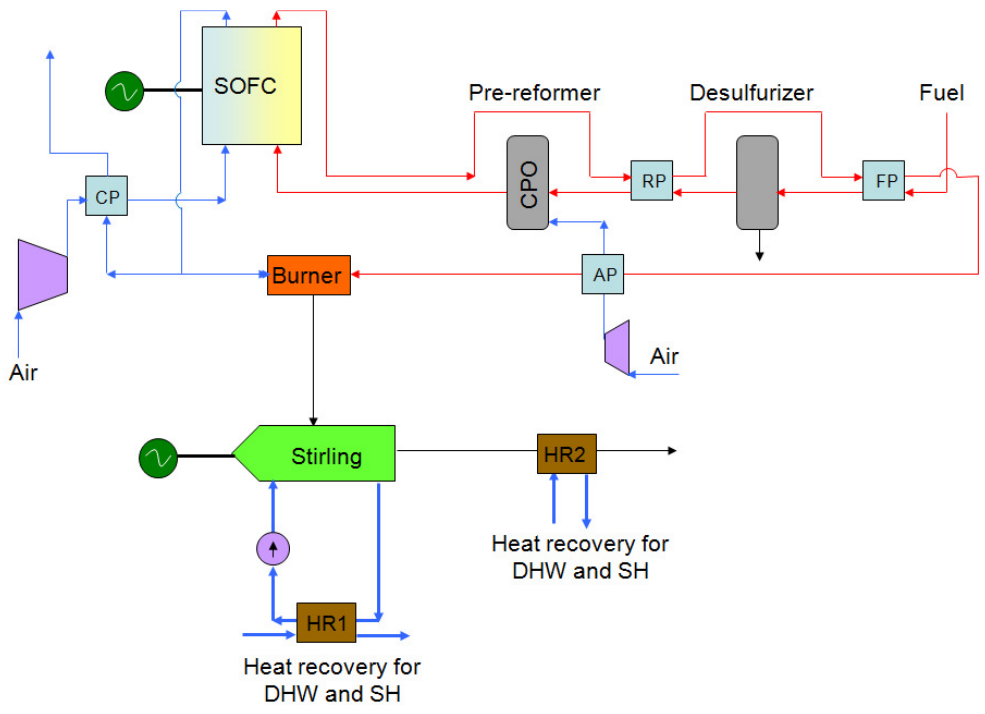

Figure 6. SOFC micro-cogeneration system with Stirling engine fuelled by natural gas

[Catalytic Partial Oxidizer (CPO), Cathode Pre-heater (CP), Fuel Pre-heater (FP), Heat exchangers (HR1 and HR2) for heat recovery for Domestic Hot Water (DHW) and Space Heating (SH), Reformer Pre-heater (RP), Air Pre-heater (AP)]

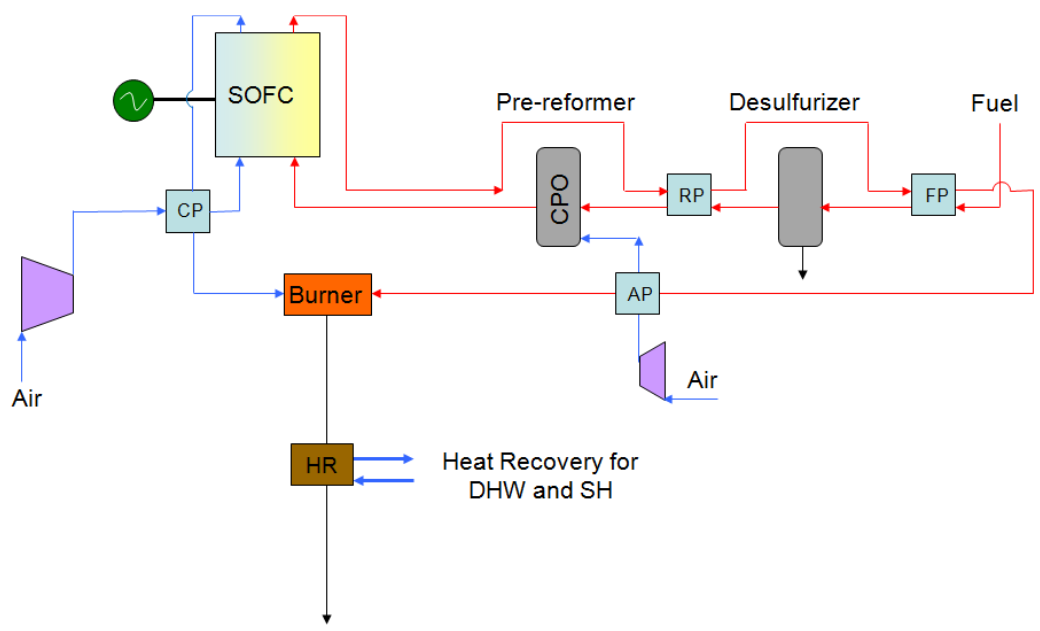

Figure 7. SOFC micro-cogeneration system (stand-alone) fuelled by natural gas [Catalytic Partial Oxidizer (CPO), Cathode Pre-heater (CP), Fuel Pre-heater (FP), Heat exchanger (HR) for heat recovery for Domestic Hot Water (DHW) and Space Heating (SH), Reformer Pre-heater (RP), Air Pre-heater (AP)]

To recover as much as possible the available chemical energy of fuels, the off-fuel (after the anode side of the SOFC) and off-air (after the cathode side of the fuel cell) are burnt in a catalytic burner. Gases coming out of the burner are then used in a Stirling engine and finally they are used to heat water in heat recover HR2 when the Stirling is switched on, c.f. Figure 2, Figure 4 and Figure 6. In this case, heat can be recovered by HR1 heat exchanger (cold sink of the Stirling engine) as well. Hot water from HR1 and HR2 is used for both Domestic Hot Water (DHW) and Space Heating (SH) as it produced at the common temperature of $45^{\circ} \mathrm{C}$. Otherwise, when the Stirling engine is switched off the gases are used to directly heat the water by means of heat recovery exchanger HR, c.f. Figure 3, Figure 5 and Figure 7. It is also proposed to vary the configuration of the system when the Stirling engine is switched off. In this case, the off-air splitter after cathode side of SOFC is closed and all the off-air from the cathode is used in the Cathode Pre-heater (CP), and successively used into the burner. Again, Figure 2, Figure 4 and Figure 6 
represent SOFC system with Stirling operating, with an off-air splitter to distribute off-air for both CP and burner smartly. Figure 3, Figure 5 and Figure 7 represent SOFC system when Stirling engine without using off-air splitter, and all off-air are directed into the burner after cathode $\mathrm{CP}$.

\section{Ground source heat pump}

A ground source heat pump is proposed to cover user heat demand, both $\mathrm{SH}$ and DHW consumption. The heat pump produces heat with high efficiency, and it contributes to vary Heat-to-Power (H/P) ratio of the system, due to its electricity consumption.

GSHP is simulated on the basis of international and Italian standards [30, 31] with hourly simulation which also considers the monthly energy results, as proposed in a previous study [32]. In order to simplify the simulation model, a constant ground temperature of $9{ }^{\circ} \mathrm{C}$ (annual average temperature for the simulated resort, Copenhagen) is set for the heat source. A temperature of $45{ }^{\circ} \mathrm{C}$ for outlet water from the heat pump condenser is set as well, both for SH and DHW.

According to the simulations, maximum heating power demand for the group of five houses is resulted to be $53 \mathrm{~kW}$. Considering a GSHP with a nominal power of $35 \mathrm{~kW}$ it is possible to cover $99 \%$ of the heating demand. In authors' opinion it is not advantageous from the economic point of view to cover the entire heating demand by GSHP as already proved in previous studies [32-34]. An auxiliary electric heater (with an efficiency fixed at 0.9 ) is also considered for the case when heating demand is larger than $35 \mathrm{~kW}$. The seasonal efficiency of the system is not substantially reduced by such choice as the electric heater is used for a few hours yearly only. Thermodynamic results show that less than $1 \%$ of total heat is provided by electric heaters (see the following sections).

\section{Stirling engine}

Stirling engines are noted for their quiet operation and the ease with which they can be connected to almost any heat source. When used as bottoming cycle for a SOFC, then the total plant efficiency increases significantly, as shown in [29]. Here, the Stirling engine is analysed with the aim of managing variation of $\mathrm{H} / \mathrm{P}$ ratio of the system, for both in the short time (days) and in the long time (months) periods. The reason is that space-heating demand is present in winter and mid-seasons, while it is nearly zero during warmer months. During the nights, electricity is the only energy demand and it is used to charge electric cars. Stirling engine uses waste heat at high temperature from SOFC to increase electricity production and overall efficiency of the system. In this study, a pseudo-Stirling cycle, which provides better agreement with engine performance data, is modelled/simulated according to [29]. Configuration of the Stirling engine is not affected by the kind of fuel because it uses the exhausted gases coming out of the burner, see Figure 2, Figure 4 and Figure 6.

\section{THERMAL AND ELECTRICITY DEMANDS}

As already mentioned, the system is supposed to supply energy (electricity and heat) for a group of five houses. According to [25, 35, 36], a total energy demand of 14.85 MWh for DHW, 53.63 MWh for SH and 15.14 MWh for electricity is estimated. Figure 8 represents energy demands for each season: winter (December, January and February), spring (March, April and May), summer (June, July and August) and autumn (September, October and November). As seen during the winter heat demand is very high and then it decreases during spring months until it reaches to the lowest level during summer months before rising again during the autumn months. The need for DHW is almost the same year around even though it decreases slightly during the summer months. The need for electricity is more or less the same for different seasons, approximately 4 MWh per season. 
Energy request

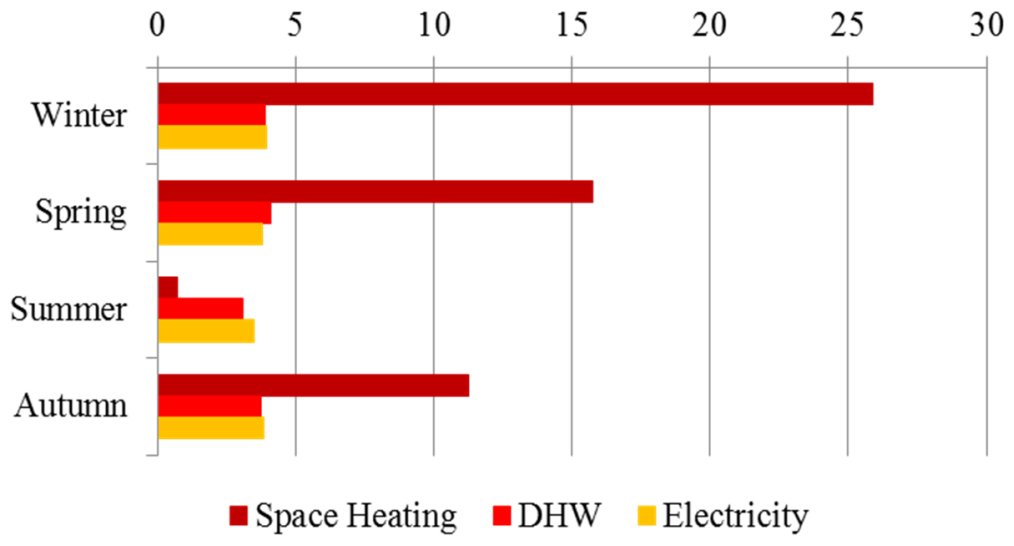

Figure 8. Energy demands (DHW, SH and electricity) divided by season (all data are in $\mathrm{MWh}$ )

\section{MOBILITY MODEL}

To complete the data needed for the simulations, a reference year for the daily driving distance of an average Danish car driver is also provided. Five electric vehicles are simulated, one for each house. A mobility model for these cars (daily driving distance) is estimated using a Random function, to define a driving distance reference year for each car. According to [37] and [38] an average annual driving distance of approximately $15,600 \mathrm{~km}(42.7 \mathrm{~km} /$ day $)$ is proposed so that the Random function is set to vary between $21.35 \mathrm{~km}$ and $64.05 \mathrm{~km}$ (thus the average daily driving is very close to $42.7 \mathrm{~km}$ ). Table 2 summarizes dataset created and Figure 9 shows the driving distance for the first 15 days simulated.

Table 2. Summary of daily driving distance reference year for each car

\begin{tabular}{cccccc}
\hline & Car 1 & Car 2 & Car 3 & Car 4 & Car 5 \\
\hline Upper limit $[\mathrm{km}]$ & 64.00 & 64.00 & 64.00 & 64.00 & 64.00 \\
Lower limit $[\mathrm{km}]$ & 22.00 & 22.00 & 21.40 & 21.50 & 21.40 \\
Number of values & 365 & 365 & 365 & 365 & 365 \\
Average [km] & 42.72 & 42.98 & 42.66 & 42.45 & 42.83 \\
Standard deviation $[\mathrm{km}]$ & 12.35 & 13.20 & 12.19 & 12.29 & 12.30 \\
\hline
\end{tabular}

Daily driving distance

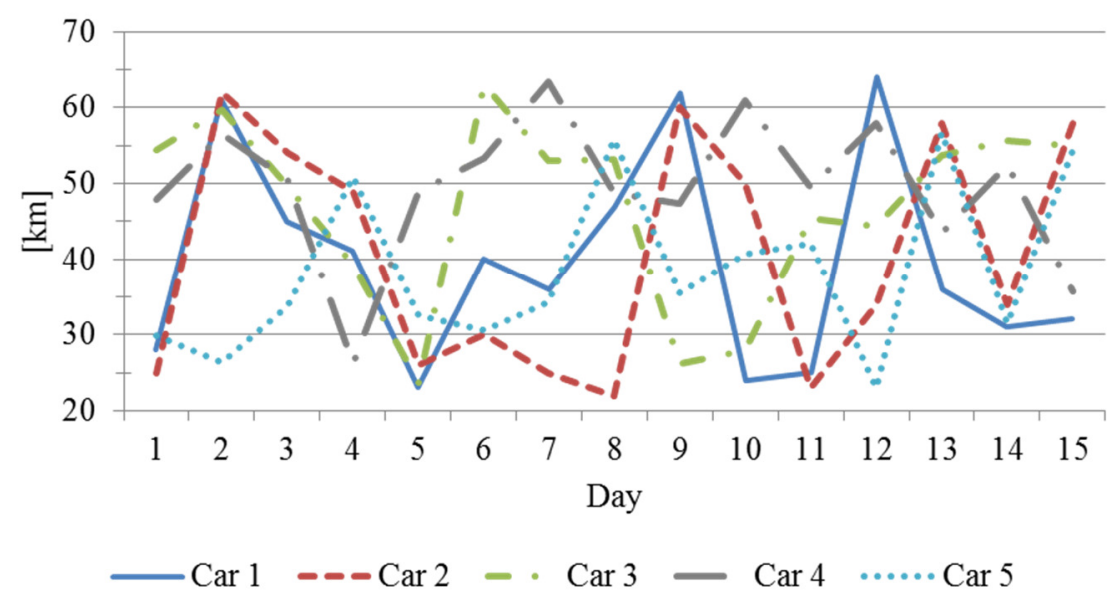

Figure 9. Daily driving distance, first 15 days of simulation for each car 
In the study fuel efficiency for the electric car is assumed to be $0.15 \mathrm{kWh} / \mathrm{km}$ (according to [37]), while for the traditional (gasoline) car the fuel efficiency is assumed to be $20 \mathrm{~km} / \mathrm{L}$ (according to [39]).

\section{OPERATION AND CONTROL STRATEGIES}

The cogeneration system is composed by different equipment (mainly SOFC, Stirling engine and GSHP), and it produces different types of energy (electricity and heat) for different uses (SH, DHW, electrical energy for electricity user and charging the vehicle). The efficient management of energy fluxes is necessary to achieve high energy efficiency of the system. This can be done by increasing the utilization of the fuel cell as much as possible and by matching the system $\mathrm{H} / \mathrm{P}$ ratio for the user electrical demand so that the aim is to maximize the grid independency of the system. The following strategies are proposed to operate simultaneously:

- Strategy to Manage Stirling Engine (MSE);

- Electric Load Following (ELF);

- Charging Electric Vehicle (CEV).

Thanks to the availability of hot water produced during night when electric vehicles are charged, it is also proposed to use the Peak Shaving (PS) strategy in order to decrease peak heat demand during daytime.

\section{Managing Stirling engine}

The use of the Stirling engine is directed to increase the efficiency of the system. The heat available at high temperature from SOFC may increase electricity production (when used in the Stirling engine) and therefore it may decrease fuel consumption. The advantages of using Stirling engine can be depicted by three viewpoints as:

- Related to GSHP - If heat demand (SH and DHW) is lower than $30 \mathrm{~kW}$, Stirling is switched on. This decreases H/P ratio (because the amount of heat available to user from SOFC decreases and electric power produced by the system increases). Furthermore, GSHP works at higher partial ratio because it has to satisfy the user heating demand. The global effect is that the efficiency of the overall system increases. For example, referring to one hour of operation, if electricity demand is $6 \mathrm{kWh}$ and heat demand is $10 \mathrm{kWh}$, then SOFC without Stirling working with natural gas (assuming $\mathrm{H} / \mathrm{P}=0.812$ and electricity efficiency of 0.530 ) produces $7.33 \mathrm{kWh}$ of electricity and $5.95 \mathrm{kWh}$ of heat, while heat pump produces 4.05 $\mathrm{kWh}$ of heat. Total primary energy consumption of the system is $15.05 \mathrm{kWh}$. SOFC with Stirling engine using natural gas features H/P ratio equal to 0.758 and electricity efficiency is 0.595 thanks to a higher energy conversion efficiency. In this case the cogeneration system will produce $7.43 \mathrm{kWh}$ of electricity and 5.63 $\mathrm{kWh}$ of heat. Heat pump will provide $4.37 \mathrm{kWh}$ of heat, operating at a higher partial load ratio than the previous case. Thanks to higher efficiency, the system has a lower primary energy consumption $(13.58 \mathrm{kWh})$;

- Related to electric vehicle - If electric car is charging, Stirling is switched on to increase electricity production and energy efficiency of the system;

- Related to heat storage - In case that the water tank cannot store more thermal energy (full capacity), Stirling is switched on to change H/P ratio of the system. This decreases heat production and thus avoids the increase in heat losses from the system. Electricity production of SOFC decreases because part of the electricity demand is generated by the Stirling engine.

It is considered that Stirling can be switched on only if SOFC electricity production is higher than $5 \mathrm{~kW}$ in order to ensure that enough waste heat from SOFC is available to correctly operate the engine. According to the simulation, with this strategy Stirling 
engine works $42 \%$ of the total time, mainly during night (when electric cars are charging) and summer (when user's heating demand is lower - in this season SH demand is nearly zero).

\section{User demand (Electric load following strategy)}

Electric Load Following (ELF) is an operation strategy proposed in [40] and already used by the authors in previous studies [25, 26]. This operation strategy considers both user electricity and heat demands together and simultaneously. It assumes that the user heat demand is covered partly by the recovered heat from the SOFC and partly by the heat pump. An Electric Equivalent Load (EEL) parameter is also defined as the electricity demand for both electrical usage and for the heat pump. EEL is thus a function of the user electricity demand, which takes into account the total heat demand (both DHW and $\mathrm{SH}$ ), the $\mathrm{H} / \mathrm{P}$ ratio, the auxiliary consumption and the heat pump Coefficient Of Performance (COP). In the system considered here, H/P ratio and so ELF strategy vary depending on the state of the Stirling engine (on or off). The main advantages of the ELF operation strategy is related mainly to the high thermodynamic efficiency of the system (thanks to high utilization factor of SOFC) and to the possibility of limiting the size of water tank (thanks to a better correlation of the H/P ratio between the system and the user).

The equations proposed in [25] require the user electricity demand ( $\left.E_{\mathrm{USER}}\right)$, the user heat demand ( $\left.H_{\text {USER }}\right)$, and the efficiencies of both the SOFC ( $\left.\eta_{\text {trans }}\right)$ and the GSHP (COP) as input data [eq. (1) and eq. (2) in Table 3]. The overall transmitted efficiency of the SOFC ( $\left.\eta_{\text {trans }}\right)$ is defined considering both auxiliaries and inverter efficiencies, which is fixed at 0.92 . The definition for the COP of the heat pump considers the hourly variation as a function of the ground temperature, the tank temperature and the partial load (Table 3). Electrical demand for charging EV is not considered in the ELF calculation.

Table 3. Definition of ELF control strategy

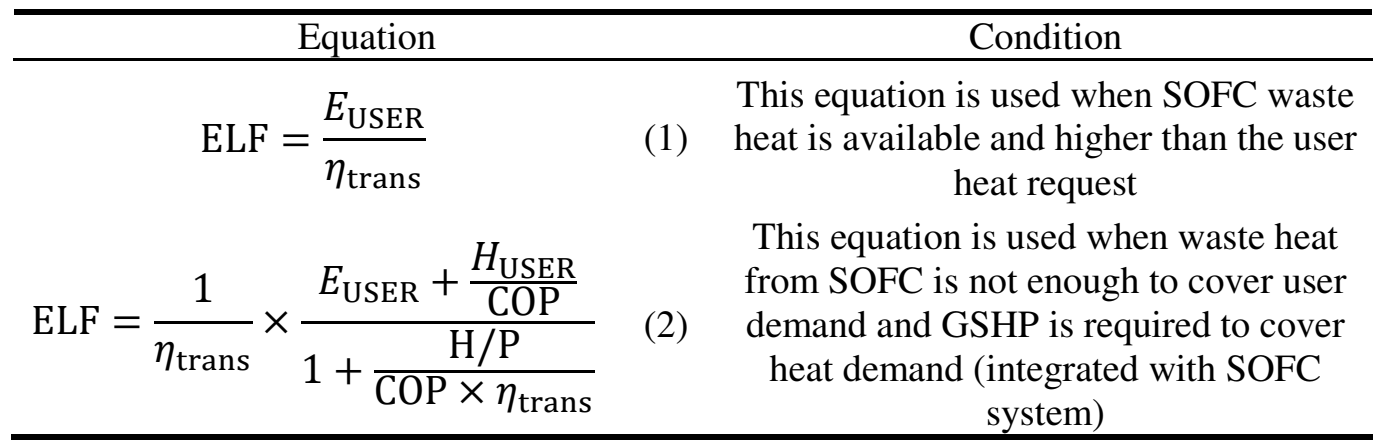

\section{Charging electric vehicle/Peak shaving strategy}

The main scope of charging electric vehicles is to charge the batteries using electricity produced by SOFC-Stirling engine system only, thus avoiding consumption from the grid and maximizing the efficiency of the system. For this reason the charging is scheduled during night, when usually cars are not used and total energy demand is low. The advantages are related to the possibility to store heat recovered from SOFC into the water tank (because during night heat demand is lower than production) in order to use it during daytime (especially when there is peak demands). This results in increasing overall efficiency of the system and also avoiding part-load operation of SOFC during night.

Charging Electric Vehicle (CEV) is the strategy used here to manage charging process. It considers both the nominal power of the SOFC ( $\mathrm{SOFC}_{\text {nom,power }}$ ), energy demands of the user as electricity demand ( $\left.E_{\mathrm{USER}}\right)$, heating demand ( $\left.H_{\mathrm{USER}}\right)$, and DHW 
demand (DHW USER $)$ and the electricity request for charging the cars $\left(E C_{\text {charge,demand }}\right)$. The charging process starts at $10 \mathrm{PM}$ and continues until the battery is fully charged. The duration of the charging process is related to the previous day's consumption and the $E C_{\text {charge }}$ (electricity available for charging) parameter that varies hour-by-hour:

$$
E C_{\text {charge }}=\min \left[\mathrm{SOFC}_{\text {nom,power }}-\left(E_{\mathrm{USER}}+\frac{H_{\mathrm{USER}}+\mathrm{DHW}_{\mathrm{USER}}}{\mathrm{COP}_{\text {avg }}}\right) ; E C_{\text {charge,demand }}\right]
$$

During the night the electric cars are charging, the electricity requested is mainly covered by the fuel cell (under CEV strategy), and the heat demand (both SH and/or heat for the DHW) is low. So heat recovered from the SOFC is stored (in the tank) and used during the following day to cover the peak demand. Heat is also stored also when charging process ends.

A PS strategy is proposed to be used during morning when there is peak demand both in summer and winter as displayed in Figure 10. It is expected/assumed that the maximum request is between $7 \mathrm{AM}$ to $9 \mathrm{AM}$, when there is high demand for both $\mathrm{SH}$ and DHW. It is also predictable that the PS strategy would decrease the heat request during these hours. The main effect is the reduction of the maximum heat power required by the heat pump with a double advantage, namely a lower investment cost and operation at higher partial load ratio for the heat pump.

Heat demand

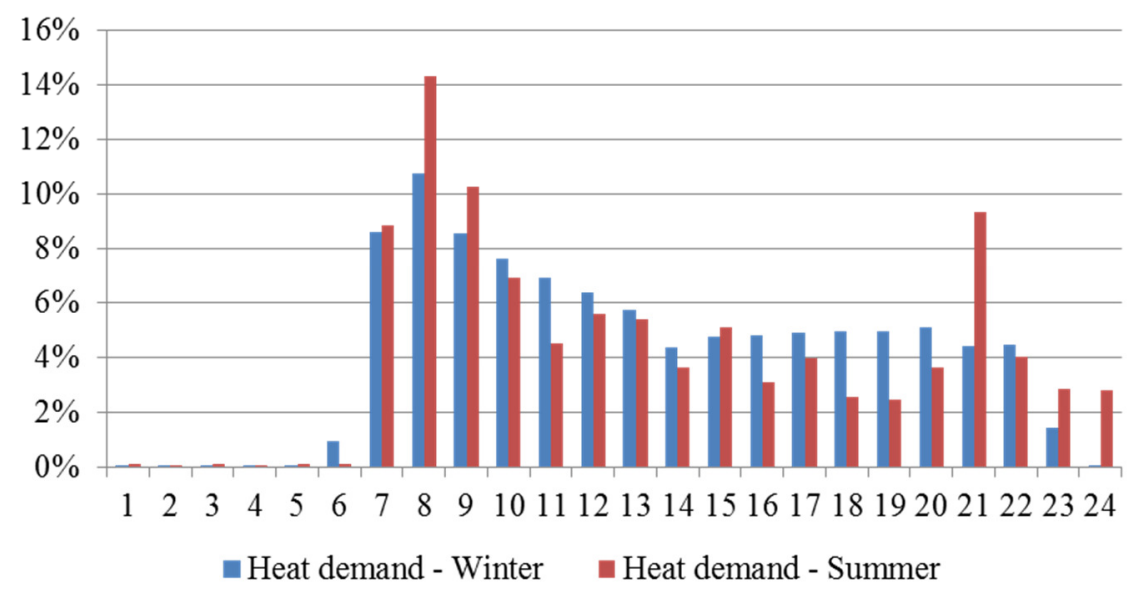

Figure 10. Average hourly heating demand divided by winter and summer

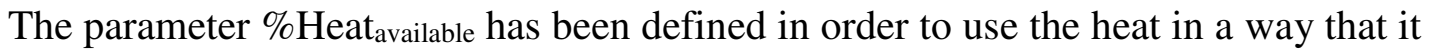
aims to shave the peak demand. Here, it is defined that peak hours are between 7 AM-11 AM, and for each hour only a part of the stored heat is available while electric cars are charging. If after $11 \mathrm{AM}$ there is still heat available then it can be used to cover the user heat demand. Table 4 summarises parameters values for each hour of the peak.

Table 4. Values of $\%$ Heat $_{\text {available }}$ parameter

\begin{tabular}{cc}
\hline Hour (AM) & \% Heat $_{\text {available }}$ \\
\hline 7 & $24 \%$ \\
8 & $39 \%$ \\
9 & $23 \%$ \\
10 & $11 \%$ \\
11 & $3 \%$ \\
\hline
\end{tabular}




\section{ENERGY ANALYSIS OF THE SYSTEM}

The micro-cogeneration system proposed here ("innovative system") is compared to a "traditional system" by means of energy analysis in order to evaluate its potential advantage. The traditional system is a natural gas boiler (for user's thermal energy demand) and the grid distributor (providing user's electricity demand). In the traditional system, a gasoline car is also considered. The comparison is based on the total Primary Energy consumption $(P E)$ of each system, and further the Primary Energy Saving $(\% P E S)$ of the innovative system with respect to the separate energy production is evaluated.

For the traditional system the primary energy consumption $P E_{\text {trad.sys }}$ is estimated as eq. (4):

$$
P E_{\text {trad.sys }}=\frac{H_{\mathrm{USER}}}{\eta_{\text {boiler }}}+\frac{E_{\mathrm{USER}}}{\eta_{\mathrm{el}}}+F_{\mathrm{car}}
$$

where $H_{\text {USER }}$ is the user heat demand and $\eta_{\text {boiler }}$ is the seasonal mean efficiency of a traditional natural gas fired boiler used in the traditional system to cover heating and DHW demands (assumed to be 0.9). E ESER is the user electricity demand, and $\eta_{\mathrm{el}}$ is the efficiency of electric energy supply from the grid, considering generation with a traditional power plant and grid efficiency (fixed at $43.9 \%$ ). $F_{\text {car }}$ is the fuel consumption of a traditional car with a lower heating value of $9.7 \mathrm{kWh} / \mathrm{L}$ (considered here).

The primary energy consumption for the innovative system $P E_{\text {inno.sys }}$ is calculated as eq. (5):

$$
P E_{\text {inno.sys }}=F_{\mathrm{SOFC}}+\frac{E_{\mathrm{GRID}}}{\eta_{\mathrm{el}}}
$$

where $F_{\mathrm{SOFC}}$ is the primary energy (fuel) consumption of the SOFC, and $E_{\mathrm{GRID}}$ is the electricity net consumption from the grid.

$\% P E S$ (percentage of primary energy saving) is calculated by comparing the primary energy consumption of the traditional system and that of the innovative system. \%PES parameter is defined as eq. (6):

$$
\% P E S=1-\frac{P E_{\text {inno.sys }}}{P E_{\text {trad.sys }}}
$$

\section{RESULTS AND DISCUSSION}

According to the simulations, the \%PES of the innovative SOCF-Stirling-GSHP system with respect to the traditional one results to be between 46 and $49 \%$ depending on the fuel used by the fuel cell (Figure 11). The largest part of the energy saving is due to the electricity self-production. The highest efficiency is obtained by the use of Natural Gas (NG) as fuel, with a \%PES of $48.9 \%$. The lowest efficiency is obtained when the micro-cogeneration system uses ammonia as fuel, with a $\% P E S$ of $46.4 \%$. Nevertheless, the type of fuel seems do not affect strongly on the primary energy saving. Figure 12 through Figure 16 represent energy balances for the innovative system fed by ammonia, DME, ethanol, methanol and natural gas, respectively. Even if energy fluxes change when considering different types of fuel, it is possible to notice the following points: 
- Heat demand is mainly covered by GSHP. For example if ammonia is used, GSHP provides approximately $44 \mathrm{MWh}$ on a total heat production of $69 \mathrm{MWh}$;

- Auxiliary electric heater is used to cover peak demands that happens only for few hours during the year. The maximum contribution to heat demand is $529 \mathrm{kWh}$ (system fuelled by ethanol) which is less than $1 \%$ of the total heat request;

- As Stirling engine is used to increase electricity production, heat losses from the water tank are between $800 \mathrm{kWh}$ and 2,146 kWh, which means that they are in the order of few percent of total heating demand ( $\mathrm{SH}+\mathrm{DHW}$ demand). Heat losses are caused by temporal mismatching between heat production and demand, in particular during summer time when electricity demand is similar to the winter time but heating demand is nearly close to zero (Figure 8);

- Electricity use from the grid is low. The largest quantity of electricity from the grid is $1,677 \mathrm{kWh}$ (associated with system fuelled by ethanol) which is lower than $4 \%$ of total electricity production. Further, electricity injection to grid is even less. The system could be used as stand-alone if a battery would be installed;

- The main electricity utilizations is from the user demand, GSHP and charge of electric vehicle, with similar weights. For example, in case of natural gas, the user electricity demand is $15,143 \mathrm{kWh}$, while electric car needs $11,691 \mathrm{kWh}$ and GSHP uses 12,769 kWh of electricity.

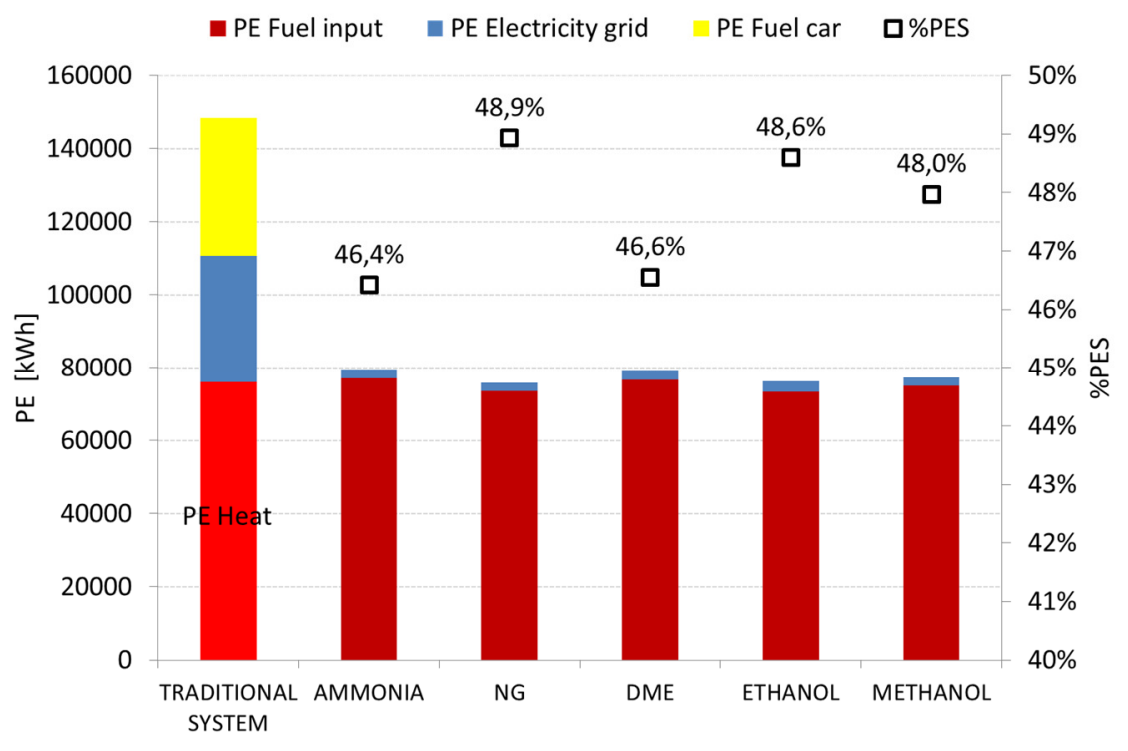

Figure 11. Different contributions to the primary energy consumption for the traditional system and the innovative system according to the different types of fuel and primary energy saving (for the traditional system PE consumed as "fuel input" is not present while there is PE consumed as natural gas by the boiler for heat production)

Another advantage of EV charging during the night time is that the SOFC works more continuously, thus avoiding frequent shut-down and start-up of the stacks with consequent thermal stresses and possible failure and/or breakdowns. Once the SOFC system is started then it will operate nonstop until it is forced to shut-down, e.g. for service, etc.

Figure 12 to Figure 16 show the energy balance of the system for each fuel. It is noticeable that energy input by fuel varies between $73 \mathrm{MWh}$ to $77 \mathrm{MWh}$ depending on the fuel. Electricity produced by SOFC and Stirling engine varies between about $39 \mathrm{MWh}$ to $41 \mathrm{MWh}$, while electricity demand from the grid varies only from 1.3 to 1.6 MWh. Electricity delivered to the grid varies between $350 \mathrm{kWh}$ to $440 \mathrm{kWh}$. Heat produced by the heat pump varies between $57 \%$ to $67 \%$ of the total heat demand. 


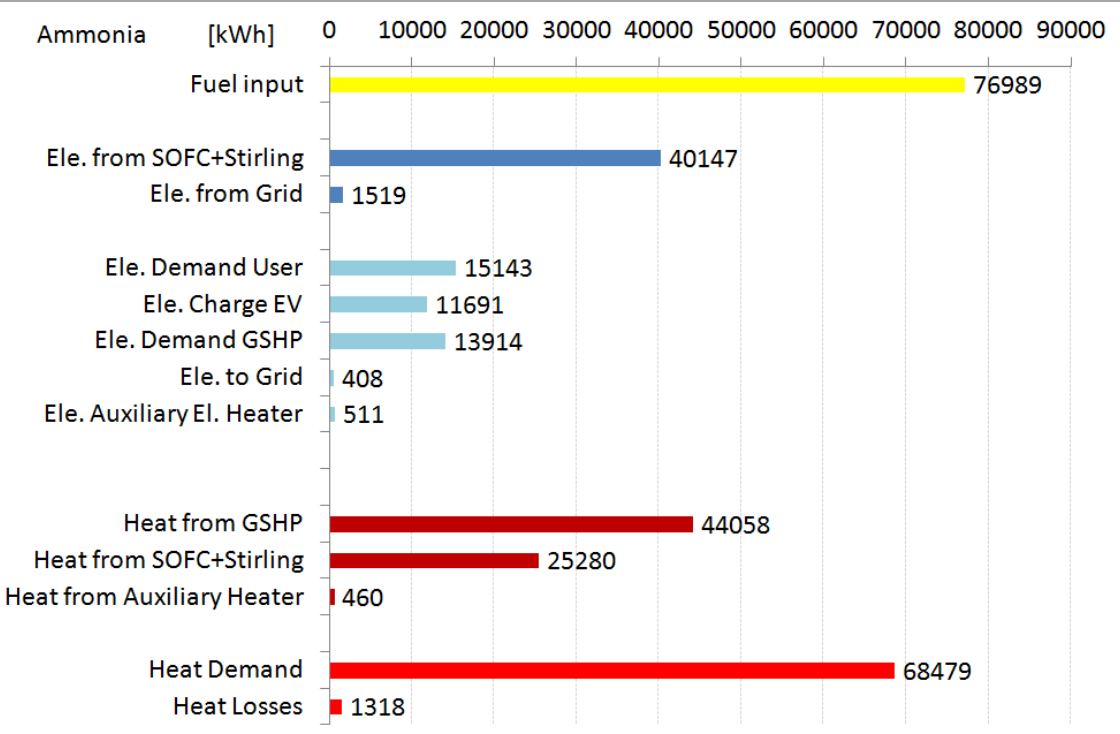

Figure 12. Energy fluxes for system fuelled by ammonia in $\mathrm{kWh}$

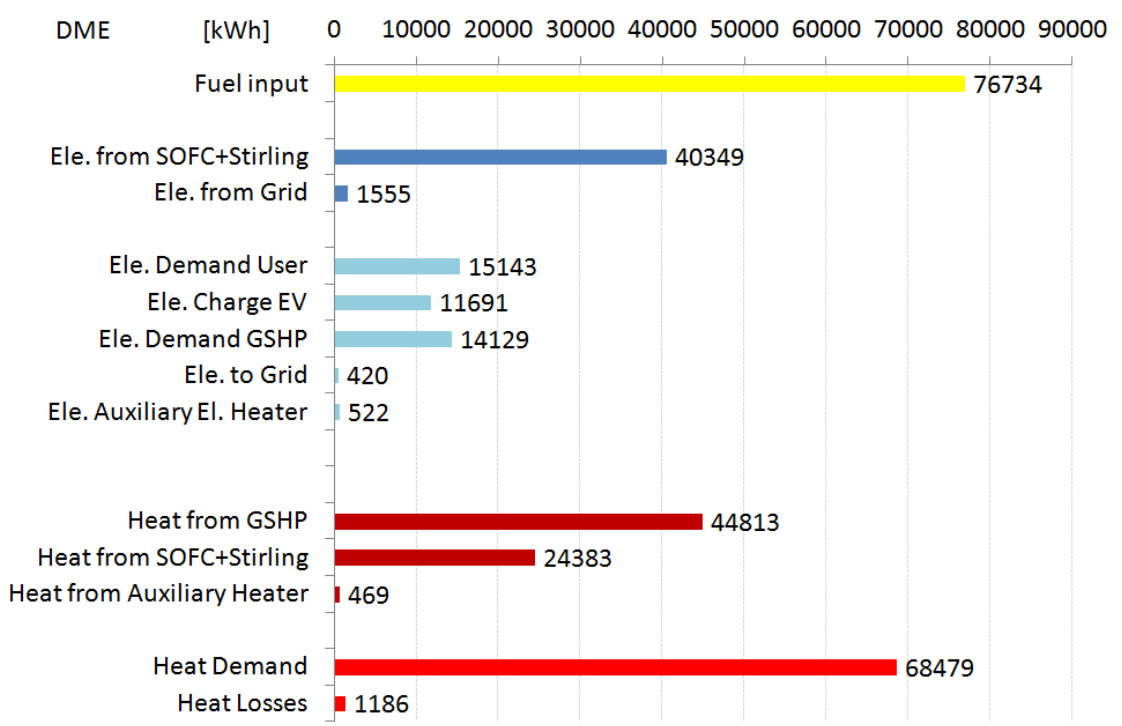

Figure 13. Energy fluxes for system fuelled by DME in $\mathrm{kWh}$

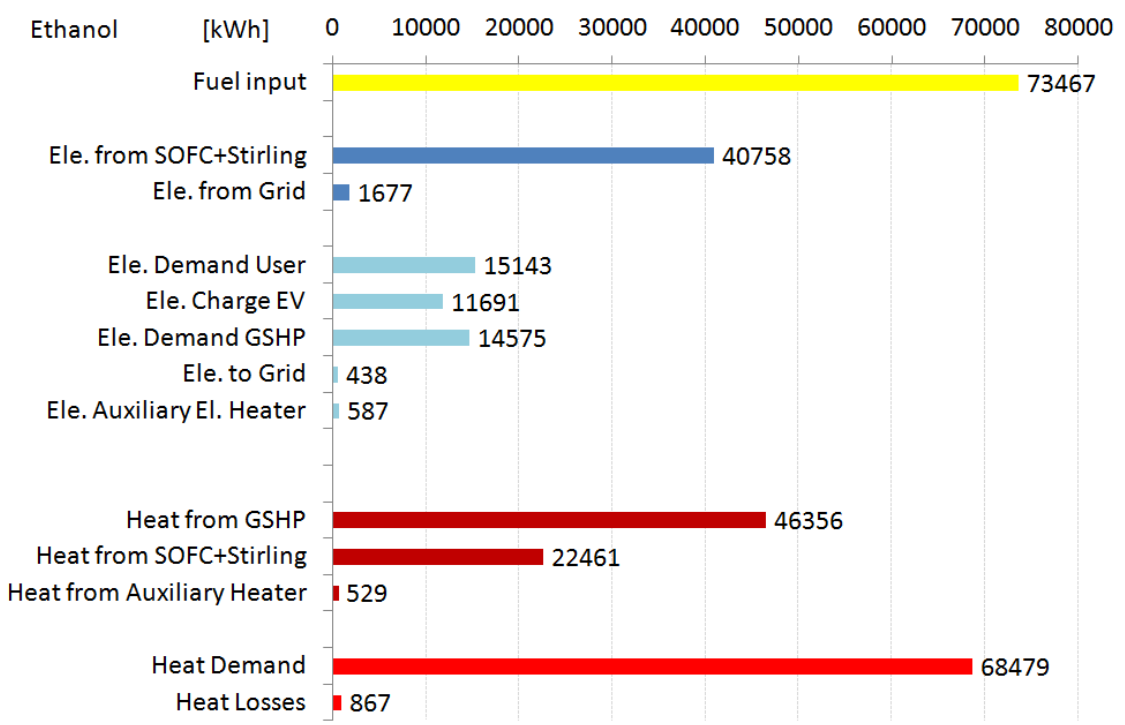

Figure 14. Energy fluxes for system fuelled by ethanol in $\mathrm{kWh}$ 


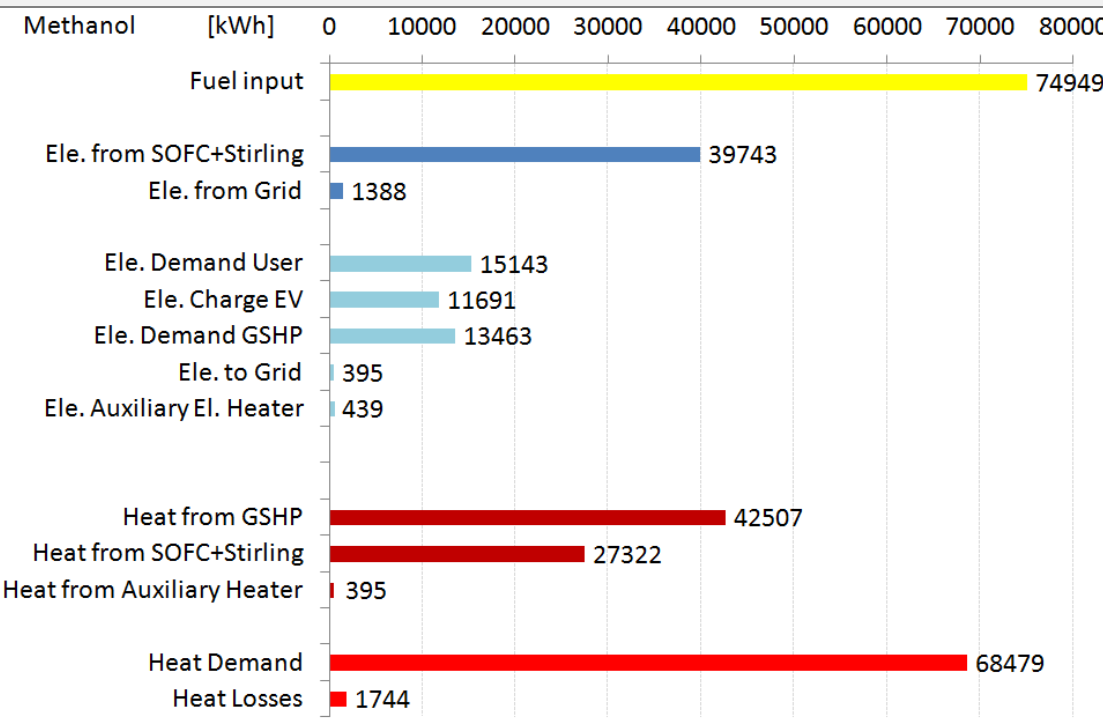

Figure 15. Energy fluxes for system fuelled by methanol in kWh

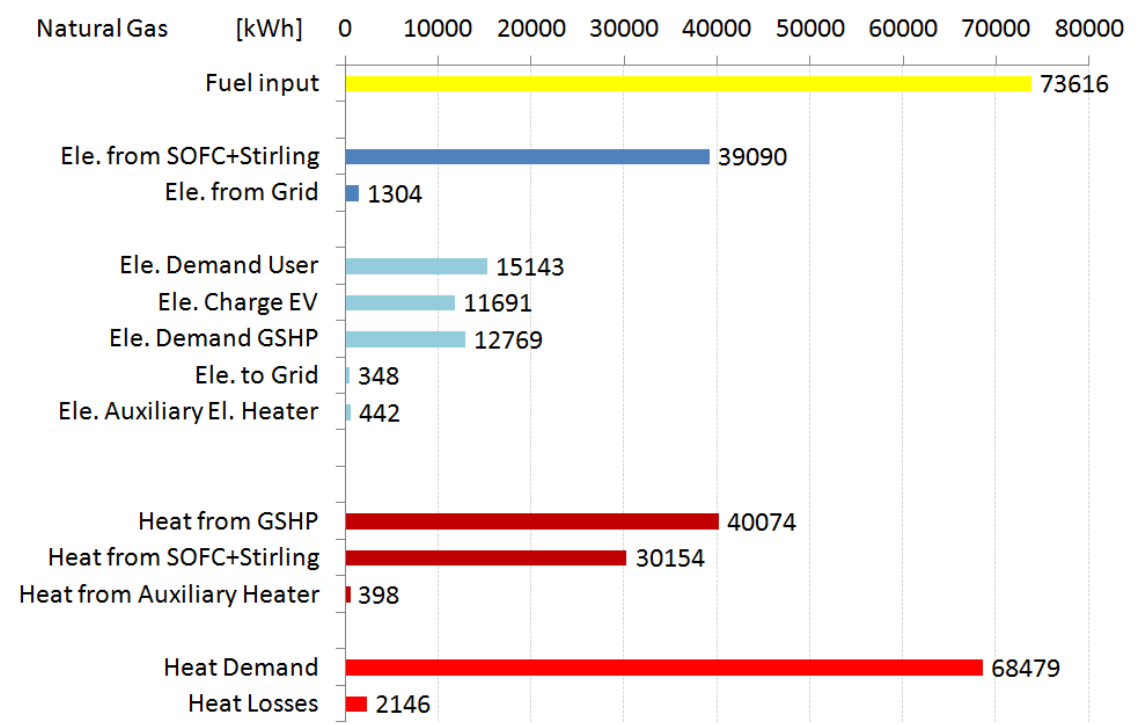

Figure 16. Energy fluxes for system fuelled by natural gas in $\mathrm{kWh}$

\section{CONCLUSIONS}

In this paper an innovative micro-cogeneration system with electric cars is simulated and energy performance is analysed. The system is composed mainly by a SOFC that generates electricity and heat. This heat is used to cover the SH and DHW demands of a group of five residential buildings, and also to run a Stirling engine as a bottoming cycle for the SOFC. Innovative strategies are also analysed with different aims, such as efficiently managing energy production to cover user demands, smartly handling electric car charging by minimizing electrical consumption from the grid, and profitably using the heat available to shave heat demand during peak time. Electric load following strategy relates SOFC electricity production to the user energy requests and increases overall energy saving and profitability of the system. The advantages of considering the charging of the electric cars at nights are related to a less variable utilization factor of the SOFC and to the lower heat peak demand.

A ground source heat pump is proposed to cover heat demand when heat from SOFC is not enough, and by which to manage variation of user's H/P ratio. Stirling engine is managed with a specific strategy to minimize heat losses when heat production is higher 
than request and when the tank storage if fully charged. The proposed micro-cogeneration system is analysed with different types of fuel in order to mark its flexibility. Results show high thermodynamic performances: primary energy saving with respect to a traditional system (with petrol car) is in between $46 \%$ to $49 \%$. Thus energy advantages of the innovative system are substantially independent on fuel type.

\section{REFERENCES}

1. DTU, International Energy Report, Energy Systems Integration for the Transition to Non-fossil Energy Systems, 2015, ISBN 978-87-550-3970-4.

2. Miedema, J. H., Moll, H. C. and Benders, R. M. J., Environmental and Energy Performance of the Biomass to Synthetic Natural Gas Supply Chain, J. Sustain. Dev. Energy Water Environ. Syst., Vol. 4, No. 3, pp 262-278, 2016, https://doi.org/10.13044/j.sdewes.2016.04.0021

3. Nastasi, B. and Lo Basso, G., Hydrogen to Link Heat and Electricity in the Transition towards Future Smart Energy Systems, Energy, Vol. 110, pp 5-22, 2016, https://doi.org/10.1016/j.energy.2016.03.097

4. Lo Basso, G., de Santoli, L., Albo, A. and Nastasi, B., H2NG (Hydrogen-natural Gas Mixtures) Effects on Energy Performances of a Condensing Micro-CHP (Combined Heat and Power) for Residential Applications: An Expeditious assessment of Water Condensation and Experimental Analysis, Energy, Vol. 84, pp 397-418, 2015, https://doi.org/10.1016/j.energy.2015.03.006

5. Hossain, A. K., Smith, D. I. and Davies, P. A., Effects of Engine Cooling Water Temperature on Performance and Emission Characteristics of a Compression Ignition Engine Operated with Biofuel Blend, J. Sustain. Dev. Energy Water Environ. Syst., Vol. 5, No. 1, pp 46-57, 2017, https://doi.org/10.13044/j.sdewes.d5.0132

6. Moder, J., Obara, S. and Morizane, Y., Operation Strategy for a Power Grid Supplied by 100\% Renewable Energy at a Cold Region in Japan, J. Sustain. Dev. Energy Water Environ. Syst., Vol. 2, No. 3, pp 270-283, 2014, https://doi.org/10.13044/j.sdewes.2014.02.0022

7. Faria, R., Marques, P., Moura, P., Freire, F., Delgado, J. and de Almeida, A.T., Impact of the Electricity Mix and use Profile in the Life-cycle assessment of Electric Vehicles, Renewable and Sustainable Energy Reviews, Vol. 24, pp 271-287, 2013, https://doi.org/10.1016/j.rser.2013.03.063

8. Amirioun, M. H. and Kazemi, A., A New Model based on Optimal Scheduling of Combined Energy Exchange Modes for Aggregation of Electric Vehicles in a Residential Complex, Energy, Vol. 69, pp 186-198, 2014, https://doi.org/10.1016/j.energy.2014.02.063

9. Metz, M. and Doetsch, C., Electric Vehicles as Flexible Loads - A Simulation approach using Empirical Mobility Data, Energy, Vol. 48, No. 1, pp 369-374, 2012, https://doi.org/10.1016/j.energy.2012.04.014

10. Samweber, F., Fischhaber, S. and Nobis P., Electric Mobility as a Functional Energy Storage in Comparison to On-site Storage Systems for Grid Integration, Energy Procedia, Vol. 73, pp 94-102, 2015, https://doi.org/10.1016/j.egypro.2015.07.572

11. Sibilio, S. and Rosato, A., Energy Technologies for Building Supply Systems: MCHP (Chapter), Energy Performance of Buildings: Energy Efficiency and Built Environment in Temperate Climates, pp 291-318, 2016, https://doi.org/10.1007/978-3-319-20831-2_15

12. Zheng, C. Y., Wu, J. Y., Zhai, X. Q., Yang, G. and Wang, R. Z., Experimental and modeling Investigation of an ICE (Internal Combustion Engine) based Micro-cogeneration Device considering Overheat Protection Controls, Energy, Vol. 101, pp 447-461, 2016, https://doi.org/10.1016/j.energy.2016.02.030

13. Asaee, S. R., Ugursal, V. I. and Beausoleil-Morrison, I., Techno-economic Evaluation of Internal Combustion Engine based Cogeneration System Retrofits in Canadian 
Houses - A Preliminary Study, Applied Energy, Vol. 140, pp 171-183, 2015, https://doi.org/10.1016/j.apenergy.2014.11.068

14. Chmielewski, A., Gumiński, R., Mączak, J., Radkowski, S. and Szulim, P., Aspects of Balanced development of RES and distributed Micro-cogeneration use in Poland: Case Study of a $\mu \mathrm{CHP}$ with Stirling Engine, Renewable and Sustainable Energy Reviews, Vol. 60, pp 930-952, 2016, https://doi.org/10.1016/j.rser.2016.01.131

15. Valenti, G., Silva, P., Fergnani, N., Campanari, S., Ravidà, A., Di Marcoberardino, G. and Macchi, E., Experimental and Numerical Study of a Micro-cogeneration Stirling Unit under Diverse Conditions of the Working Fluid, Applied Energy, Vol. 160, pp 920-929, 2015, https://doi.org/10.1016/j.apenergy.2015.05.112

16. Brandoni, C., Arteconi, A., Ciriachi, G. and Polonara, F., Assessing the Impact of Micro-generation Technologies on Local Sustainability, Energy Conversion and $\begin{array}{lllll}\text { Management, } & \text { Vol. } & \text { 87, }\end{array}$ https://doi.org/10.1016/j.enconman.2014.04.070

17. Maghanki, M. M., Ghobadian, B., Najafi, G. and Galogah, R. J., Micro Combined Heat and Power (MCHP) Technologies and Applications, Renew. Sustain. Energy Rev., Vol. 28, pp 510-524, 2013, https://doi.org/10.1016/j.rser.2013.07.053

18. Karellas, S. and Braimakis, K., Energy-exergy Analysis and Economic Investigation of a Cogeneration and Trigeneration ORC-VCC Hybrid System utilizing Biomass Fuel and Solar Power, Energy Conversion and Management, Vol. 107, pp 103-113, 2016, https://doi.org/10.1016/j.enconman.2015.06.080

19. Algieri, A. and Morrone, P., Techno-economic Analysis of Biomass-fired ORC Systems for Single-family Combined Heat and Power (CHP) Applications, Energy Procedia, Vol. 45, pp 1285-1294, 2014, https://doi.org/10.1016/j.egypro.2014.01.134

20. Thu, K., Saha, B. B., Chua, K. J. and Bui, T. D., Thermodynamic Analysis on the Part-load Performance of a Microturbine System for Micro/mini-CHP Applications, Applied Energy, Vol. 178, pp 600-608, 2016, https://doi.org/10.1016/j.apenergy.2016.06.106

21. Amirante, R. and Tamburrano, P., Novel, Cost-effective Configurations of Combined Power Plants for Small-scale Cogeneration from Biomass: Feasibility Study and Performance Optimization, Energy Conversion and Management, Vol. 97, pp 111-120, 2015, https://doi.org/10.1016/j.enconman.2015.03.047

22. Modi, A., Bühler, F., Andreasen, J. G. and Haglind, F., A Review of Solar Energy based Heat and Power Generation Systems, Renewable and Sustainable Energy Reviews, Vol. 67, pp 1047-1064, 2017, https://doi.org/10.1016/j.rser.2016.09.075

23. Busato, F., Lazzarin, R. and Noro, M., Experimental Analysis of Photovoltaic Cogeneration Modules, International Journal of Low Carbon Technologies, Vol. 3, No. 4, pp 221-244, 2008, https://doi.org/10.1093/ijlct/3.4.221

24. Babak, T. and Duic, N., Possibility of Heat Pump use in Hot Water Supply Systems, J. Sustain. Dev. Energy Water Environ. Syst., Vol. 4, No. 3, pp 203-2015, 2016, https://doi.org/10.13044/j.sdewes.2016.04.0017

25. Vialetto, G. and Rokni, M., Innovative Household Systems based on Solid Oxide Fuel Cells for a Northern European Climate, Renewable Energy, Vol. 78, pp 146-156, 2015, https://doi.org/10.1016/j.renene.2015.01.012

26. Vialetto, G., Noro, M. and Rokni, M., Innovative Household Systems based on Solid Oxide Fuel Cells for the Mediterranean Climate, International Journal of Hydrogen Energy, Vol. 40, No. 41, pp 14378-14391, 2015, https://doi.org/10.1016/j.ijhydene.2015.03.085

27. Sehar, F., Pipattanasomporn, M. and Rahman, S., Demand Management to Mitigate Impacts of Plug-in Electric Vehicle Fast Charge in Buildings with Renewables (Available Online), Energy, ISSN 0360-5442, 2016, https://doi.org/10.1016/j.energy.2016.11.118 
28. AA.VV, TRNSYS: A Transient System Simulation Program, TRNSYS Manual, Version 16, 2004.

29. Rokni, M., Thermodynamic Analysis of SOFC (Solid Oxide Fuel Cell) - Stirling Hybrid Plants using Alternative Fuels, Energy, Vol. 61, pp 87-97, 2013, https://doi.org/10.1016/j.energy.2013.06.001

30. UNI/TS 11300-4, Renewable Energy and other Generation Systems for Space Heating and Domestic Hot Water Production (in Italian), Ente Nazionale Italiano di Unificazione, Milano, Italy.

31. EN 14825, Air Conditioners, Liquid Chilling Packages and Heat Pumps, with Electrically driven Compressors, for Space Heating and Cooling - Testing and Rating at Part Load Conditions and Calculation of Seasonal Performance, European Committee for Standardisation, 2008.

32. Busato, F., Lazzarin, R. and Noro, M., Energy and Economic Analysis of different Heat Pump Systems for Space Heating, International Journal of Low Carbon Technologies, Vol. 7, No. 2, pp 104-112, 2012, http://dx.doi.org/10.1093/ijlct/cts016

33. Bagarella, G., Lazzarin, R. and Noro, M., Sizing Strategy of On-off and modulating Heat Pump Systems based on Annual Energy Analysis, International Journal of Refrigeration, Vol. 65, pp 183-193, 2016, https://doi.org/10.1016/j.ijrefrig.2016.02.015

34. Bagarella, G., Lazzarin, R. and Noro, M., Annual Simulation, Energy and Economic Analysis of Hybrid Heat Pump Systems for Residential Buildings, Applied Thermal $\begin{array}{lllll}\text { Engineering, } \quad \text { Vol. } & 99, \quad \text { pp }\end{array}$ https://doi.org/10.1016/j.applthermaleng.2016.01.089

35. Annex 42, The Simulation of Building-integrated Fuel Cell and other Cogeneration Systems (COGEN-SIM), IEA Energy Conservation in Buildings \& Community Systems.

36. Typical Heat Consumption, Varde Forsyning A/S (in Danish), http://vardeforsyning.dk/Varme/Typisk-varmeforbrug.aspx,

[Accessed: 01-February-2016]

37. Wu, Q., Nielsen, A. H., Østergaard, J., Cha, S. T., Marra, F. and Andersen, P. B., Modeling of Electric Vehicles (EVs) for EV Grid Integration Study, $2^{\text {nd }}$ European Conference SmartGrids \& E-Mobility, 2010.

38. Standardv Rider for Traffic Data til OSPM modellen, Tetraplan A/S, 2001.

39. Prud'homme, R. and Koning, M., Electric Vehicles: A Tentative Economic and Environmental Evaluation, Transport Policy, Vol. 23, pp 60-69, 2012, https://doi.org/10.1016/j.tranpol.2012.06.001

40. Kavvadias, K. C., Tosios, A. P. and Maroulis, Z. B., Design of a Combined Heating, Cooling and Power System: Sizing, Operation Strategy Selection and Parametric Analysis, Energy Conversion and Management, Vol. 51, No. 4, pp 833-845, 2010, https://doi.org/10.1016/j.enconman.2009.11.019 